\title{
ONREGMATIGHEIDSBEWUSSYN AS ELEMENT VAN ANIMUS INIURIANDI BY INIURIA
}

Inleiding

\section{Uitgangspunt in regspraak}

Daar kan met stelligheid verklaar word dat tot en met die beslissing van die Hoogste Hof van Appèl in Le Roux v Dey (2010 4 SA 210 (HHA)), die regspraak, ook die Appèlhof, algemeen as uitgangspunt aanvaar het dat animus iniuriandi as tradisionele vereiste vir iniuria in beginsel twee komponente het, te wete die rig van die wil om 'n persoonlikheidsgoed te krenk en die bewussyn dat die krenking onregmatig is (wilsgerigtheid en onregmatigheidsbewussyn). In Hofmeyr v Minister of Justice (1993 3 SA 131 (A) 154) stel Hoexter AR hierdie uitgangspunt onomwonde soos volg: "Injuria is the wrongful and intentional infringement of an interest of personality. In an action for damages based on injuria the plaintiff must prove intent (dolus, animus injuriandi) on the part of the defendant ... Dolus encompasses not only the intention to achieve a particular result, but also the consciousness that such a result would be wrongful" (sien bv ook Nydoo $v$ Vengtas 19651 SA 1 (A) 15; SAUK v O'Malley 19773 SA 394 (A) 403 405); Matlou v Makhubedu 19781 SA 946 (A) 962; Ramsay v Minister van Polisie 19814 SA 802 (A) 818; Pakendorf v De Flamingh 19823 SA 146 (A) 157; Dantex Investment Holdings (Pty) Ltd v Brenner 19891 SA 390 (A) 396; Tödt v lpser 19933 SA 577 (A) 586; Herschelman NO v Botha 19941 SA 28 (A) 35; Minister for Justice and Constitutional Development v Moleko [2008] 3 All SA 47 (HHA) 64; Rudolph v Minister of Safety and Security 2009 5 SA 94 (HHA) 100; sien verder Maisel $v$ Van Naeren 19604 SA 836 (K) 840; Marais v Groenewald 20011 SA 634 (T) 645; en Heyns v Venter 2004 3 SA 200 (T) 208).

Anders as wat Jansen AR in Ramsay v Minister van Polisie (supra 807) ten onregte te kenne gee, word onregmatigheidsbewussyn weens beleidsoorwegings egter nie by alle iniuriae as noodsaaklike bestanddeel van animus iniuriandi geverg nie. Daarom verdien Botha WnAR in Ramsay $v$ Minister van Polisie (supra 818) se kritiek instemming:

"[Jansen AR] aanvaar, na aanleiding van die posisie by laster, dat animus injuriandi, wat onregmatigheidsbewussyn verg, in die algemeen 'n element is van alle inbreuke op die persoonlikheid wat as injuriae aangemerk word. Ek aanvaar dit nie. Ek laat die moontlikheid oop dat daar by bepaalde vorme van injuria na die eise van regsbeleid aanspreeklikheid kan bestaan in die afwesigheid van onregmatigheidsbewussyn by die dader. In der waarheid word my benadering onderskraag deur die huidige stand van die regspraak. Dit val nie te betwyfel nie dat daar in die regspraak ... oor 'n tydperk van jare met betrekking tot sekere vorms van injuria 'n standpunt ingeburger is wat 
beteken dat by sekere injuriae onregmatigheidsbewussyn by die dader geen voorvereiste vir aanspreeklikheid is nie."

Die feit dat vir uitsonderings voorsiening gemaak word, doen geensins afbreuk aan die uitgangspunt dat onregmatigheidsbewussyn in beginsel 'n vereiste vir animus iniuriandi is nie. In Dantex Investment Holdings (Pty) Ltd $v$ Brenner (supra 396) spreek Grosskopf AR hom baie duidelik hieroor uit:

"[l]t is now accepted that dolus encompasses not only the intention to achieve a particular result, but also the consciousness that such a result would be wrongful or unlawful ... In Ramsay's case supra the majority of this Court (per Botha JA) doubted whether animus injuriandi, including consciousness of wrongfulness, was a necessary element in all forms of injuria ... In the present case we are, of course, not concerned with an injuria but with a claim under the extended lex Aquilia in which the plaintiff relies upon fault in the form of dolus. The policy considerations which might affect the elements of various types of injuria consequently do not arise in the present case, and I do not read the judgment of Botha JA as casting doubt on the proposition that dolus or animus injuriandi in principle requires consciousness of unlawfulness."

\section{Uitsonderingsgevalle}

\section{Onregmatige vryheidsontneming en onregmatige beslaglegging op goed}

Gevalle van iniuria wat onregmatigheidsbewussyn weens beleidsoorwegings nie vir animus iniuriandi vereis nie, is onregmatige vryheidsontneming, onregmatige beslaglegging op goed en aanspreeklikheid van die media weens laster. In Hofmeyr v Minister of Justice (supra 154-155) verklaar Hoexter AR met betrekking tot eersgenoemde twee gevalle:

"It is clear that without dolus the action for an injuria would lie neither in Roman law nor in Roman-Dutch law ... It is equally clear, however, that in a limited class of injuriae the current of precedent has in modern times flowed strongly in a different direction. In this limited class of delicts dolus remains an ingredient of the cause of action, but in a somewhat attenuated form, in the sense that it is no longer necessary for the plaintiff to establish consciousness on the part of the wrongdoer of the wrongful character of his act. Included in this limited class are cases involving false imprisonment and the wrongful attachment of goods."

In Smit v Meyerton Outfitters (1971 1 SA 137 (T) 139), waarna Hoexter AR verwys, maak die hof dit duidelik dat "[i]n die geval van die actio injuriarum ... die skuldbegrip met twee oorwegings te make" het: die verweerder moet naamlik eerstens "opsetlik (intentionally) gehandel het" en tweedens moet hy "geweet het dat die handeling onregmatig is", maar dat "[i]n die geval van onregmatige arrestasie, hoewel dit uit die actio injuriarum ontwikkel het, ... die tweede oorweging nie 'n vereiste vir aanspreeklikheid nie". Hierop lewer Hoexter AR in Hofmeyr v Minister of Justice (supra 157) soos volg kommentaar: "In my opinion the succinct dictum in Smit $v$ Meyerton Outfitters ... embodies a correct statement of our modern law. The application of the principle therein stated furthermore entails practical consequences which seem to me to be both sensible and just." Hierdie standpunt is teenswoordig gevestigde reg wat sowel onregmatige 
vryheidsontneming (sien bv ook Relyant Trading (Pty) Ltd $v$ Shongwe [2007] 1 All SA 375 (HHA) 377; Tödt v Ipser supra 586-587; Ramsay v Minister van Polisie supra 818-819; Minister of Correctional Services v Tobani 20035 SA 126 (OK) 133; Louw v Minister of Safety and Security 20062 SACR 178 (T) 185; en Le Roux v Minister of Safety and Security 20094 SA 491 (N) 497), as onregmatige beslaglegging betref (sien bv ook Sheriff, Pretoria East $v$ Meevis 20013 SA 454 (HHA) 460; Minister of Finance $v$ EBN Trading (Pty) Ltd 19982 SA 319 (N) 328-329; en Trust Bank van Africa Bpk v Geregsbode, Middelburg 19663 SA 391 (T) 393). 'n Mens het inderdaad hier met vorme van skuldlose aanspreeklikheid te make aangesien nóg opset (onregmatigheidsbewussyn) nóg nalatigheid nodig om is aanspreeklikheid te vestig (sien Relyant Trading (Pty) Ltd v Shongwe supra 377; Sheriff, Pretoria East $v$ Meevis supra 460; Neethling en Potgieter NeethlingPotgieter-Visser Deliktereg (2010) 385; en Neethling, Potgieter en Visser Neethling's Law of Personality (2005) 119-120 185).

Beleidsoorwegings wat hierdie afwykings van die animus iniuriandi-begrip regverdig, is eerstens dat dit meestal staatsamptenare is wat by onregmatige vryheidsberowing en beslaglegging betrokke is en die betrokkenes, so gesien, in 'n verhouding van volslae ongelykheid teenoor mekaar staan: aan die een kant die magtige, gesigslose staatsorganisasie met sy dwangmiddels waarteen geen weerstand gebied kan word nie, en feitlik onbeperkte finansiële vermoë, en aan die ander kant die feitlik weerlose enkeling (sien Neethling en Potgieter Deliktereg 385; Neethling's Law of Personality 186 vn 596; Meevis v Sheriff, Pretoria East 19992 SA 389 (T) 393; en Van Rensburg en Neethling "Actio Iniuriarum - Animus Iniuriandi Onregmatigheidsbewussyn nie 'n Vereiste nie" 1973 THRHR 303-304). Tweedens vereis die grondwetlike legaliteitsbeginsel dat staatsamptenare geen gesag het of enige funksie mag verrig buiten wat regtens aan hulle opgelê word nie; daarom moet die vryheidsontneming of beslaglegging op goed deur staatsamptenare objektief gesien aan die betrokke regsvoorskrifte voldoen en by hierdie beoordeling speel die amptenaar se bona fides of bewussyn van die regmatigheid of nie van sy optrede geen rol nie (sien Minister of Correctional Services v Tobani supra 133; Louw v Minister of Safety and Security supra 185; en Le Roux v Minister of Safety and Security supra 497). In hierdie opsig versterk die verskansing van die betrokke persoonlikheidsregte (die fisiese vryheid, fama en privaatheid) in die Handves van Regte boonop hulle beskerming en gee aan hulle 'n hoër status in die sin dat onder andere die optrede van staatsamptenare teen hierdie regte getoets mag word (vgl Van Eeden $v$ Minister of Safety and Security (Women's Legal Centre Trust, as amicus curiae) 20031 SA 389 (HHA) 397). Dienooreenkomstig verklaar Magid R in Minister of Finance $v$ EBN Trading (Pty) Ltd (supra 329) tereg dat "[i]t seems ... to accord better with the human rights culture of the new South Africa ... that in cases involving wrongful imprisonment or the wrongful detention of goods that it should no longer be necessary for the plaintiff to establish consciousness on the part of the wrongdoer of the wrongful character of his act. Certainly [there are] no compelling grounds of public policy to differentiate between the wrongful detention of a person or his property". Billikheid, regverdigheid en grondwetlike imperatiewe eis dus dat die staat aanspreeklik gehou word 
selfs al ontbreek dit hom aan onregmatigheidsbewussyn (sien Neethling en Potgieter Deliktereg 385; Neethling's Law of Personality 186 vn 596; Meevis $\checkmark$ Sheriff, Pretoria East supra 393).

In hierdie verband moet ook verwys word na $C v$ Minister of Correctional Services (1996 4 SA 292 (T)), waar die actio iniuriarum gebaseer was op 'n onregmatige VIGS-toets op ' $n$ gevangene en dus privaatheidskending. Die hof (304-306), op die voetspoor van Whittaker $v$ Roos and Bateman; Morant $v$ Roos and Bateman (1912 AD 92) en Hofmeyr v Minister of Justice (supra) (sien Neethling's Law of Personality 106 vn 267252 vn 276) wat albei ook oor die skending van die persoonlikheidsregte van gevangenes gegaan het, beslis dat kleurlose animus iniuriandi (dws waar onregmatigheidsbewussyn ontbreek omdat die verweerder bona fide opgetree het), aanspreeklikheid vestig. Dit behoef geen betoog nie dat die beleidsoorwegings wat kleurlose opset as voldoende vir aanspreeklikheid op grond van onregmatige vryheidsontneming en beslaglegging op goed ag, eweseer ook hier geld. Knobel ("HIV-toetse, Toestemming en Onregmatigheidsbewussyn" 1997 THRHR 536) betoog tereg dat "[g]esien die uiters ongelyke verhouding tussen gevangenisowerheid en gevangene, $\ldots$ daar waarskynlik regspolities veel ten gunste van so 'n ontwikkeling gesê [kan] word".

\section{Aanspeeklikheid van die media weens laster}

Dit bring my by aanspeeklikheid van die media weens laster. In SAUK $v$ O'Malley (supra 403) bekragtig Rumpff AR die algemene uitgangspunt dat animus iniuriandi by laster "die geestesgesteldheid ... om die bepaalde gevolg ... te wil, met die wete dat die gewilde gevolg onregmatig sal wees", omvat (sien bv ook Nydoo v Vengtas supra 15; Pakendorf v De Flamingh supra 157; Herschelman NO v Botha supra 35; Maisel v Van Naeren supra 840; en Marais $v$ Groenewald supra 645). Hierna volg die howe 'n afwykende benadering ten aansien van die media en vervang animus iniuriandi deur strikte aanspreeklikheid (sien Pakendorf $v$ De Flamingh supra 156-158). In National Media Ltd v Bogoshi (1998 4 SA 1196 (HHA) 12101211) maak die hof egter ' $n$ radikale ommekeer en bevind dat die aanvaarding van strikte aanspreeklikheid duidelik verkeerd is, onder andere omdat dit in stryd is met die demokratiese imperatief dat die openbare belang die beste gedien kan word deur die vrye vloei van inligting en die rol wat die media in hierdie verband vervul. Die hof (1213-1214) is egter nie bereid om bloot die gemeenregtelike posisie van aanspreeklikheid gebaseer op animus iniuriandi te herstel nie, maar bepaal dat die afwesigheid van onregmatigheidsbewussyn nie opgewerp mag word waar daar nalatigheid aan die kant van die mediaverweerder was nie. (Dieselfde benadering is al in Hassen v Post Newspapers (Pty) Ltd 19653 SA 562 (W) gevolg; en sien ook Pakendorf $v$ De Flamingh supra 154-155.) Volgens Hefer AR (1214) "there are compelling reasons for holding that the media should not be treated on the same footing as ordinary members of the public by permitting them to rely on the absence of animus injuriandi, and ... it would be appropriate to hold media defendants liable unless they were not negligent in the circumstances of the case". Die resultaat is dat nalatigheid as aanspreeklikheidsgrondslag van die media vir laster erken word (sien ook 
Khumalo v Holomisa 20025 SA $401(\mathrm{KH})$ 415-416; en Marais v Groenewald supra 644-646). In Mthembi-Mahanyele v Mail \& Guardian Ltd (2004 6 SA 329 (HHA) 350) word onomwonde verklaar dat "the form of fault in defamation actions against the press is negligence rather than intention to harm". Uit 'n beleidsoogpunt gesien, kom dit voor of, in die proses van die afweging van die twee teenoorstaande fundamentele regte by laster - die regte op die goeie naam en vryheid van uitdrukking - nalatigheidsaanspreeklikheid van die media 'n billiker balans tussen hulle bewerkstellig (Marais $v$ Groenewald supra 645) en daarom die beste kompromis bied tussen aanspreeklikheid gebaseer op animus iniuriandi wat voorkeur aan die beskerming van die reg op vryheid van spraak verleen omdat die media hulle te maklik op afwesigheid van onregmatigheidsbewussyn sou kon beroep, en strikte aanspreeklikheid wat weer voorkeur aan die beskerming van die reg op die goeie naam verleen en sodoende die demokratiese imperatief dat die vrye vloei van inligting die openbare belang die beste dien, verydel (sien Neethling's Law of Personality 166 vn 390167 vn 396).

\section{Slotsom}

Die slotsom is dus dat animus iniuriandi as vereiste vir iniuria in ons reg in beginsel sowel wilsgerigtheid as onregmatigheidsbewussyn as komponente verg, maar dat weens beleidsoorwegings van onregmatigheidsbewussyn afgesien kan word. Dit het reeds gebeur met betrekking tot onregmatige vryheidsontneming, onregmatige beslaglegging op goed, die onregmatige inwerking op die persoonlikheidsgoedere van gevangenes en aanspreeklikheid van die massamedia weens laster.

\section{$2 \quad$ Le Roux v Dey}

\section{$21 \quad$ Inleiding}

In hierdie uitspraak wyk Harms AP (par 39) geheel en al van die geykte benadering af en beslis dat, wat iniuria betref, "the animus iniuriandi requirement generally does not require consciousness of wrongfulness (wederregtelikheidsbewussyn)". Omdat die uitspraak op die oog af 'n ingrypende verandering van ons iniuria-reg bewerkstellig, is dit nodig om die oorwegings vir hierdie wysiging deeglik onder die loep te neem.

\section{Pandektiste versus Romeins-Hollandse reg}

Onder die opskrif, "DEFAMATION: ANIMUS INIURIANDI", verklaar Harms AP (par 26) ten aanvang dat "[i]t is trite that delictual liability depends in general terms on fault which, in the case of defamation and all other iniuriae, is fault of a particular nature, namely animus iniuriandi". Omdat die verweerders in casu afwesigheid van animus iniuriandi as verweer geopper het, vind die hof dit nodig om nogmaals die betekenis en toepassing van die verweer in die konteks van die actio iniuriarum in al sy verskyningsvorme te ondersoek. Volgens Harms AP (par 28) beteken animus iniuriandi vir die Romeins-Hollandse skrywers bloot "the intention to injure" en dit is ook die 
betekenis wat sedert Whittaker $v$ Roos and Bateman; Morant $v$ Roos and Bateman (supra 124-125) deur die Appèlhof asook deur vroeëre SuidAfrikaanse skrywers daaraan geheg word. Dit was eerste die vastelandse Pandektiste wat onregmatigheidsbewussyn of "coloured intent" as element van animus iniuriandi bygebring het, 'n ontwikkeling wat ongeveer in die middel van die vorige eeu byval by Suid-Afrikaanse skywers begin vind het (par 29 31). Hierop laat Harms AP hom soos volg uit: "In spite of my high regard for them it has to be conceded that by systemizing the Roman law concepts they did not necessarily state the Roman-Dutch law. This means that an adherence to the roots of our law does not necessarily require an adoption of Pandectist theories." Nou is dit natuurlik 'n vraag of dit vandag enigsins sin het om te vra na die oorsprong van die begrip "coloured intent" aangesien, soos uitgewys (hierbo par 1), die regspraak die afgelope 50 jaar algemeen aanvaar dat animus iniuriandi in beginsel sowel wilsgerigtheid as onregmatigheidsbewussyn as elemente omvat. Reeds in Maisel $v$ Van Naeren (supra 840) verklaar De Villiers WnR soos volg: "Underlying the conception of animus injuriandi is the principle stated by Ulpian in the Digest: injuriam nemo facit nisi qui scit se injuriam facere (D. 47.10.3.2). Thus, as is the position for dolus in general, it is essential that the alleged wrongdoer should be conscious of the wrongful character of his act ... Dolus or animus injuriandi is therefore consciously wrongful intent." En soos Boberg The Law of Delict Vol 1 Aquilian Liability (1984) v tereg aandui, "a country's law can be found in the last thirty years of its law reports". Die bevraagtekening van gevestigde gewysdereg moet dus op veel beter gronde as die historiese oorsprong - Pandektisties of Romeins-Hollandsregtelik - van 'n regsreël geskied.

\section{Regspraak}

Vervolgens fokus Harms AP juis op regspraak oor onregmatigheidsbewussyn, en verklaar (par 32):

"This court in [SAUK v O'Malley 1977 3 SA 394 (A) 403] accepted that coloured intent formed an essential part of animus iniuriandi for purposes of defamation. The statement was in context obiter and it will be recalled that this case created an exception to the general requirement of animus iniuriandi by holding that the public media could not escape liability by relying on its absence. The ratio was later overruled in Bogoshi [ $\mathrm{v}$ Van Vuuren NO; Director, Office for Serious Economic Offences 19961 SA 785 (HHA)]. As far as iniuria in general is concerned, Jansen JA sought to hold in [Ramsay $v$ Minister van Polisie 19814 SA 802 (A)] that coloured intent was a general requirement but the majority (per $A S$ Botha AJA) held otherwise. It held, significantly, that whether or not coloured intent should be required for any particular iniuria is a matter of legal policy."

Baie aspekte van hierdie dictum is vatbaar vir kritiek. In eerste instansie het O'Malley nie beslis wat Harms AP beweer nie. Die hof het hom slegs obiter en sonder om so te beslis ten gunste van die vervanging van animus iniuriandi deur strikte aanspreeklikheid van die media uitgespreek - dit was wel die ratio decidendi in Pakendorf $v$ De Flamingh (supra). Tweedens is die verwysing na Bogoshi klaarblyklik 'n lapsus aangesien dié saak hoegenaamd nie oor laster handel nie. Harms AP bedoel sekerlik National 
Media Ltd $v$ Bogoshi (supra). Die belangrikste punt van kritiek is teen die laaste bewering in die dictum. Dit skep die indruk dat Botha WnAR beslis het dat daar by alle vorme van iniuria volgens regsbeleid bepaal moet word of onregmatigheidsbewussyn vereis moet word of nie. Ten onregte. Botha WnAR het naamlik by implikasie aanvaar dat onregmatigheidsbewussyn in beginsel ' $n$ vereiste vir iniuria is, maar dat, waar regsbeleid dit noop, daar van "coloured intent" afgesien kan word. In Dantex Investment Holdings (Pty) Ltd v Brenner (supra 396, aangehaal hierbo) verklaar Grosskopf AR ingelyks dat "I do not read the judgment of Botha JA as casting doubt on the proposition that dolus or animus injuriandi in principle requires consciousness of unlawfulness".

\section{Afwesigheid van onregmatigheidsbewussyn as verweer}

Hierna ondersoek die hof die regspraak ten einde vas te stel of "colourless intent" wel as 'n verweer teen die actio iniuriarum geopper kan word, en sê (par 33): "One seeks rather in vain for an instance where the defence was accepted. The opposite is true. It is not a defence in the case of invasion of privacy, unlawful arrest or detention, assault, defamation by the press, or wrongful attachment." In eerste instansie het dit Harms AP klaarblyklik ontgaan dat die verweer wel aanvaar is in Maisel $v$ Van Naeren (supra 841), wat hy (par 37) as 'n "commendable judgment" bestempel. Hier het die hof beslis dat die bona fide-dwaling omtrent die bestaan van privilegie as verweer by laster, onregmatigheidsbewussyn en dus animus iniuriandi uitsluit. Hoe ook al, die feit dat die verweer nog selde aanvaar is, kan myns insiens daaraan toegeskryf word dat waar die actio iniuriarum ter sprake is, 'n verweerder wat wel 'n "intention to injure" het (sien Le Roux v Dey supra par 28 hierbo), terselfdertyd meesal ook weet of besef, sy dan ook net as 'n moontlikheid (dolus eventualis), dat hy die betrokke persoonlikheidsgoed onregmatig aantas. Tweedens is dit inderdaad so, soos duidelik hierbo blyk (par 1), dat afwesigheid van onregmatigheidsbewussyn om beleidsoorwegings nie 'n verweer by onregmatige vryheidsontneming, onregmatige beslaglegging op goed en aanspreeklikheid van die massamedia weens laster is nie. Dit is egter nie die geval met privaatheidskending en aanranding nie. By aanranding staaf Bennet $v$ Minister of Police (1980 3 SA 24 $(\mathrm{K})$ ), waarna Harms AP verwys, nie sy bewering nie. Sover vasgestel kon word, het "colourless intent" nóg uitdruklik nóg by implikasie as 'n verweer in hierdie saak ter sprake gekom. Daarenteen stel die Appèlhof in Matlou $v$ Makhubedu (supra 962) in 'n geval van aanranding dit duidelik dat "[a]angesien wederregtelikheidsbewussyn ' $n$ vereiste by opset is ... kan ook, soos by oorskryding van noodweer, die opset in bepaalde omstandighede uitgesluit wees" (sien ook Kgaleng $v$ Minister of Safety and Security 20014 SA 854 (W) 865-866 en 874; en vgl Dantex Investment Holdings (Pty) Ltd v Brenner supra 396). Wat privaatheidskending in die algemeen betref, gaan Harms AP se beroep op C v Minister of Correctional Services (supra) ook nie op nie. Soos verduidelik (par 1), het dit hier oor die privaatheidskending van 'n gevangene gegaan waar "colourless intent" goedbegryplik om beleidsoorwegings nie as ' $n$ verweer aanvaar is nie. Dit geld egter nie ander gevalle van privaatheid-skending nie. In byvoorbeeld Jansen van Vuuren 
NNO v Kruger (1993 4 SA 842 (A) 849), waar 'n mediese dokter die VIGSstatus van 'n pasiënt aan vriende ('n tandarts en 'n ander geneesheer) openbaar gemaak het, aanvaar Harms AP self dat animus iniuriandi ' $n$ vereiste vir die actio iniuriarum is, en snaaks genoeg, ondersoek hy tog die verweer dat die eerste verweerder geglo het dat sy optrede geregverdig was en dat onregmatigheidsbewussyn daarom by hom ontbreek het. Hy stel dit soos volg (857):

"I am ... satisfied that [the first defendant] did have the required animus iniuriandi. It is not necessary to set out all the reasons. The essence of this defence as argued was that the first defendant truly believed that due to Vos's alleged unhygenic procedures he (Vos) had been at risk. I have already found that version to be false. In respect of Van Heerden the defence as submitted is dependent on a belief on the part of the first defendant that Van Heerden, too, had been at risk. The first defendant never suggested that in evidence. If the first defendant had had no awareness of wrongfulness and had believed that what he had done was proper, why did he mislead the plaintiff during their telephone conversation? It follows that that defence, if it was one, must fail and that the appeal must succeed" (outeur eie kursivering).

Indien afwesigheid van onregmatigheidsbewussyn nie 'n verweer by privaatheidskending is nie, moes die hof sekerlik die verweer summier verwerp het. Dit is egter veral die beslissing van die Konstitusionele Hof in NM v Smith (Freedom of Expression Institute as amicus curiae) 20075 SA $250(\mathrm{KH})$, waar dit gegaan het oor die publikasie van 'n boek wat die eiseresse se name en HIV-status openbaar maak, wat geen twyfel laat nie dat onregmatigheidsbewussyn steeds 'n noodsaaklike bestanddeel van animus iniuriandi by privaatheidskending is. Madala $R$ (265-266) beslis dat animus iniuriandi ' $\mathrm{n}$ vereiste vir die actio iniuriarum by privaatheidskending is en aanvaar (267-268) by implikasie dat animus iniuriandi onregmatigheidsbewussyn verg. Volgens hom is animus iniuriandi inbegrepe onregmatigheidsbewussyn in casu aanwesig (267-268), omdat luidens die getuienis "the respondents were certainly aware that the applicants had not given their consent or at least foresaw the possibility that the consent had not been given for the disclosure. [They therefore] knew well of the wrongfulness of their conduct and that the disclosure of private facts was likely to invade the privacy rights of the applicants". Gevolglik besluit hy "that the respondents have not rebutted the presumption that the disclosure of private facts was done with the intention to harm the applicants. Therefore the respondents had the requisite animus iniuriandi" (outeur eie kursivering). Harms AP se siening dat privaatheidskending nie onregmatigheidsbewussyn verg nie, dra dus geen gesag nie. Ten einde hierdie iniuria op een lyn met sy opvatting te bring, sou 'n ingryping van die Konstitusionele Hof verg.

\section{$25 \quad K w a a d w i l l i g e$ vervolging}

Volgens Harms AP (par 34) kom dit voor of kwaadwillige vervolging die enigste uitsondering is waar onregmatigheidsbewussyn 'n vereiste vir aanspreeklikheid is. Hy verduidelik dit soos volg:

"Malicious prosecution appears to be an exception because it has been held firmly that coloured intent is a requirement for liability. The interesting aspect of this cause of action is that it is probably the only iniuria where the plaintiff 
must prove animus iniuriandi instead of the defendant having to prove its absence. This, and the common name of the action, indicates that there is something special about this cause of action. It appears to me that this is an instance where coloured intent forms part of the wrongfulness element: public policy considerations demand that a plaintiff should only be compensated for a prosecution that was instigated without reasonable or probable cause if, in addition, it was 'malicious' (in the sense of coloured intent). The practical effect of this might be that a further inquiry into the fault element may become unnecessary because it has already been established by the plaintiff and there is accordingly nothing for the defendant to disprove."

Die hof se opvatting dat "coloured intent" deel vorm van die onregmatigheidselement is vatbaar vir kritiek, om twee redes. Eerstens, soos by herhaling reeds beklemtoon is, kan animus iniuriandi (opset) regsdogmaties beskou, nie onregmatigheid bepaal nie. Omdat "coloured intent" onregmatigheidsbewussyn omvat, kom opset logies eers ter sprake as onregmatigheid reeds vasstaan. Daar kan immers nie van onregmatigheidsbewussyn sprake wees alvorens onregmatigheid vasstaan nie. Anders gestel: die reg moet op 'n ander wyse as deur middel van opset bepaal dat onregmatigheid aanwesig is voordat ' $n$ mens daarvan bewus kan wees (sien Neethling en Potgieter Deliktereg 46 vn 55; en Neethling Van HeerdenNeethling Unlawful Competition (2008) 140). Tweedens word die opvatting dat "coloured intent" deel vorm van onregmatigheid by kwaadwillige vervolging ook nie deur resente beslissings van die Hoogste Hof van Appèl gesteun nie. In Relyant Trading (Pty) Ltd $v$ Shongwe (supra 382) verklaar Malan WnAR, sonder verwysing hoegenaamd na animus iniuriandi, dat "[w]here reasonable and probable cause for an arrest or prosecution exists the conduct of the defendant instigating it is not wrongful" (sien ook Minister for Justice and Constitutional Development $v$ Moleko supra 63; en Neethling's Law of Personality 178). Boonop het die Hoogste Hof van Appèl in sowel Minister for Justice and Constitutional Development $v$ Moleko (supra 63-64) as Rudolph v Minister of Safety and Security (supra 100), eers nadat die kwessie van onregmatigheid afgehandel is, die vraag na die aanwesigheid van "coloured intent" selfstandig ondersoek. In Minister for Justice and Constitutional Development v Moleko (supra 64, vgl Rudolph v Minister of Safety and Security supra 100) verklaar Van Heerden AR dat "[a]nimus iniuriandi includes not only the intention to injure, but also consciousness of wrongfulness", en vervolg (aanhaling uit Neethling's Law of Personality 181):

"In this regard animus iniuriandi (intention) means that the defendant directed his will to prosecuting the plaintiff (and thus infringing his personality) in the awareness that reasonable grounds for the prosecution were (possibly) absent, in other words, that his conduct was (possibly) wrongful (consciousness of wrongfulness). It follows from this that the defendant will go free where reasonable grounds for the prosecution were lacking, but the defendant honestly believed that the plaintiff was guilty. In such a case the second element of dolus, namely of consciousness of wrongfulness, and therefore animus iniuriandi, will be lacking. His mistake therefore excludes the existence of animus iniuriandi.'

The defendant must thus not only have been aware of what he or she was doing in instituting or initiating the prosecution, but must at least have foreseen the possibility that he or she was acting wrongfully, but nevertheless continued to act, reckless as to the consequences of his or her conduct (dolus eventualis)." 
So gesien, is Harms AP se obiter opvatting dat "coloured intent" deel vorm van die onregmatigheid by kwaadwillige vervolging, direk strydig met die korrekte benadering in Relyant, Moleko en Rudolph. Daar is al beslis dat growwe nalatigheid as aanspreeklikheidsvereiste vir kwaadwillige vervolging aanvaar moet word (Heyns $v$ Venter supra 208-209), maar hierdie siening word nie deur die Hoogste Hof van Appèl onderskryf nie (Rudolph v Minister of Safety and Security supra 100; vgl Relyant Trading (Pty) Ltd v Shongwe supra 378; en Minister for Justice and Constitutional Development $v$ Moleko supra 64).

\section{Bemoeiing met 'n kontraktuele verhouding en privilegie by laster}

Soortgelyke kritiek kan ook uitgespreek word teen Harms AP se siening oor die vereiste van dolus (wat onregmatigheidsbewussyn omvat) by Aquiliese aanspreeklikheid in gevalle van bemoeiing met 'n kontraktuele verhouding (sien Dantex Investment Holdings (Pty) Ltd v Brenner supra 396, aangehaal hierbo par 1) en "injurious falsehood". Hy verklaar naamlik (par 35), met verwysing na Minister of Finance $v$ Gore NO (2007 1 SA 111 (HHA)), "that animus iniuriandi is in these instances a requirement for wrongfulness because public policy considerations demand that a plaintiff should be compensated for an interference with contractual relationships only where the interference was accompanied by coloured intent". Die besware wat teen Gore geopper is (sien Neethling en Potgieter "Middellike Aanspreeklikheid vir 'n Opsetlike Delik" 2007 TSAR 619-622, waarna Harms AP vn 49 verwys), word nie hier herhaal nie, behalwe om te beklemtoon dat die hof animus iniuriandi klaarblyklik met 'n ander afkeurenswaardige gesindheid (soos kwaadwillige motief of "malice") verwar (sien Neethling en Potgieter Deliktereg 46 vn 55). Dit geld ook Harms AP (par 36) se bewering dat wat bevoorregte geleentheid of privilegie as verweer by laster betref, "[t]he plaintiff may prove that, although the defendant had published the statement on a privileged occasion, he had overstepped the mark by having spoken animo iniuriandi in the sense of coloured intent". Genoeg om te sê dat dit gevestigde reg is dat die aanwesigheid van onbehoorlike motief ("malice"), en nie animus iniuriandi nie, op die oorskryding van die perke van privilegie dui (sien Neethling's Law of Personality 149; en Burchell The Law of Defamation in South Africa (1985) 250-252 en 258). Animus iniuriandi moet ten ene male nie met onbehoorlike motief vermeng word nie, soos wat Harms AP ongelukkig doen (sien Neethling's Law of Personality 57-58 en 163 vn 55).

\section{Onaanvaarbare resultate van onregmatigheids- bewussyn as vereiste: nalatigheidsaanpreeklikheid}

Harms AP (par 37) toon vervolgens aan dat 'n suiwer Pandektistiese benadering, wat immer onregmatigheidsbewussyn verg, in die lasterreg tot onaanvaarbare resultate kan lei. Volgens hom kom dit ongerymd voor dat "a defendant who, for example, cannot establish truth and public benefit to justify defamation, can nevertheless escape liability by relying on a belief in 
either the truth or public benefit". Hierbenewens lê dit volgens die regter die ontwikkeling van hierdie deel van ons reg onder die Grondwet aan bande. Daarom is dit nie verbasend nie dat Van Dijkhorst $\mathrm{R}$ in Marais $v$ Groenewald (supra 646) daarop ingestel was om die gemenereg te ontwikkel deur te beslis dat afwesigheid van onregmatigheidsbewussyn nie 'n verweer is nie as dit aan nalatigheid te wyte is - 'n standpunt wat ook in ander sake (sien ook National Media Ltd v Bogoshi (supra 1213-1214), aangehaal hierbo par 1) en deur skrywers voorgestaan word. Hierdie opvattings verdien instemming (sien nietemin hieronder), nie alleen omdat die toepassing van die suiwer benadering tot onbillike resultate kan lei nie (sien ook Van Rensburg en Neethling 1973 THRHR 308), maar ook omdat dit nalatigheidsaanspreeklikheid voorstaan wat die grondwetlike bedeling die beste sou dien (sien hierbo par 1; sien ook Neethling "The Right to Privacy, HIV-AIDS and Media Defendants" 2008 SALJ 43-45; en Neethling's Law of Personality 5859). In Marais v Groenewald (supra 645) stel Van Dijkhorst $R$ dit soos volg:

"[D]ie vraag of die grondslag van nalatigheid in die lasterreg universele werking moet kry [is] oopgelaat in twee beslissings van ons Hoogste Hof. 'n Insiggewende oorsig van die gesag en literatuur oor die vraag is te vind in Neethling Persoonlikheidsreg 4de uitg para 4.2.3.2. Wat die lasterreg betref, stem ek saam met die geleerde skrywer se gevolgtrekking (vóór Bogoshi) dat nalatigheid as aanspreeklikheidsvereiste vir die actio iniuriarum erken moet word. Dit skep myns insiens 'n gesonde balans tussen die grondwetlik beskermde persoonlikheidsreg op die integriteit van 'n goeie naam en die reg op vryheid van spraak. Dit verhoed die met die regsgevoel botsende situasie dat ' $n$ verweerder wat willens en wetens ' $n$ ander se goeie naam skaad terwyl hy selfs grof nalatig in the waan verkeer dat wat hy doen regmatig is, skotvry bly."

\section{$28 \quad$ Nalatigheid en onregmatigheid}

In die lig hiervan is dit vreemd dat Harms AP (par 38) dit as die geskikte geleentheid beskou "to revisit with the wisdom of hindsight the judgment in Bogoshi v Van Vuuren NO; Bogoshi v Director, Office for Serious Economic Offences (1996 1 SA 785 (HHA)) - soos reeds gesê, bedoel hy sekerlik National Media Ltd v Bogoshi (supra). Hy verduidelik:

"The judgment [inter alia] dealt with the ... question of justification: the publication of a defamatory statement will be lawful if it was reasonable in the circumstances of the case. In other words the general criterion of reasonableness determines whether a defamatory publication was wrongful or not. 'Reasonableness' in this context must not be conflated with negligence. If justifiable, the question of fault cannot arise. I agree in this regard with Lewis JA [Mthembi-Mahanyele v Mail \& Guardian Ltd 20046 SA 329 (HHA) par 47]:

'However, fault need not be in issue at all if in the particular circumstances anterior inquiry shows that the publication is lawful because it is justifiable. Bogoshi indicates that the reasonableness of the publication might also justify it. In appropriate cases, a defendant should not be held liable where publication is justifiable in the circumstances - where the publisher reasonably believes that the information published is true. The publication in such circumstances is not unlawful. Political speech might, depending upon the context, be lawful even when false provided that its publication is reasonable. ... This is not a test for negligence: It determines whether, on grounds of policy, a defamatory statement should not be actionable because it is justifiably made in the circumstances.' 
It appears that on this analysis the discussion of negligence in Bogoshi might have complicated matters unnecessarily. Once it is found that the publication was unreasonable the next question should simply be whether it was published with the intent to injure."

Alhoewel hierdie dictum instemming verdien wat die onderskeid tussen onregmatigheid en nalatigheid aangaan (sien nietemin Neethling "The Protection of False Defamatory Publications by the Mass Media: Recent Developments in South Africa Against the Background of Australian, New Zealand and English Law" 2007 CILSA 121-122), kan nie daarmee akkoord gegaan word dat nalatigheid, minstens wat die media betref, uit die prentjie moet verdwyn en vervang moet word deur die "intention to injure" nie. Soos reeds uitgewys (hierbo par 1), is die nalatigheidsaanspreeklikheid van die media wat in Bogoshi beslag gekry het nie alleen in Mthembi-Mahanyele nie, maar ook, en dit is baie belangrik, deur die Konstitusionele Hof in Khumalo $v$ Holomisa (supra 415-416) bekragtig. Daarom dra Harms AP se uitspraak met betrekking tot die media nie gesag nie.

Die effek van die toepassing van die redelikheidmaatstaf vir onregmatigheid ten einde te bepaal of laster geregverdig is, is volgens Harms AP (par 39) "that mistake or bona fides might in appropriate circumstances justify a defamatory statement (that is, if it was reasonable to have been made) and that it is accordingly not necessary to require coloured intent". Hy kom gevolglik tot die slotsom dat, "especially in view of precedent and the constitutional emphasis on the protection of personality rights, that the animus iniuriandi requirement generally does not require consciousness of wrongfulness (wederregtelikheidsbewussyn)". Die opvatting dat 'n person se dwaling of bona fides verband kan hou met die redelikheid en daarom regverdiging of nie van sy optrede en bygevolg onder onregmatigheid tuisgebring kan word, lyk na 'n netjiese oplossing van die sake waar beslis is dat dwaling net ' $n$ verweer is as dit nie met nalatigheid gepaard gegaan het nie. Op die keper beskou, word die redelike persoon-toets vir nalatigheid (redelike voorsien- en voorkombaarheid) nie werklik hier toegepas nie maar eerder die redelike persoon as vergestalting van die redelikheidsmaatstaf vir onregmatigheid (sien Neethling en Potgieter Deliktereg 50 vn 76 en 318). Ook in National Media Ltd v Bogoshi (supra 1214) is Hefer AR van mening dat "[t]he indicated approach is intended to cater for ignorance and mistake at the level of lawfulness". In hierdie verband is dit verblydend dat die Hoogste Hof van Appèl nie slegs ter wille van "dogmatiese suiwerheid" beslis het dat dwaling immer onregmatigheidsbewussyn, en daarom aanspreeklikheid, uitskakel nie (sien Van Rensburg en Neethling 1973 THRHR 309). In die lig van wat hierbo (par 1) bevind is, is Harms AP se beroep op "precedent" as regverdiging vir sy besluit dat animus iniuriandi in die algemeen nie onregmatigheidsbewussyn verg nie, nie korrek nie - die omgekeerde is eerder waar: onregmatigheidsbewussyn word vereis tensy beleids-oorwegings 'n afwyking regverdig. Waarmee wel heelhartig saamgestem kan word, is dat die grondwetlike verskansing van persoonlikheidsregte versterk sal word deur die afskaffing van onregmatigheidsbewussyn. Hierdie versterking gaan egter nie ver genoeg nie. Daarom word aan die hand gedoen, soos hierbo gestel, dat nalatigheidsaanspreeklikheid in beginsel vir iniuria in die plek van animus iniuriandi (met of sonder 
onregmatigheids-bewussyn) aanvaar behoort te word - die reikwydte van opset is immers veel kleiner as dié van nalatigheid (sien Knobel "Nalatige Persoonlikheid-skrenking" 2002 THRHR 31-32; en Neethling's Law of Personality 58-59).

\section{Skerts}

Laastens glo Harms AP (par 40) nie dat "jest excludes the intention to injure" nie - dit hou verband met motief, maar "if a joke is degrading the defendant's motive does not matter". Wat skerts as 'n verweer betref, is ek steeds nie oortuig dat as 'n grap (volgens die redelike omstander) lasterlik is, die verweerder nie onkunde ten opsigte van die bedoeling om te benadeel kan opper nie. Waarom dan "intention to injure" as 'n vereiste stel as die verweerder nie op enige wyse - ook dat hy 'n grap gemaak het - kan aantoon dat sodanige wilsgerigtheid, ook in die vorm van dolus eventualis, by hom ontbreek het? (Sien Neethling's Law of Personality 165-166.)

\section{$3 \quad$ Gevolgtrekking}

Aangesien Le Roux $v$ Dey oor laster buite om die media handel, is baie aspekte van die beslissing obiter en bind howe in die toekoms dus nie. Regters kan gevolglik steeds besin oor bevraagtekenbare kwessies wat op ander verskyningsvorms van iniuria betrekking het. Dit lê nie op my weg om elke punt van kritiek (of instemming) wat hierbo uitgespreek is, hier te herhaal nie. Daarom word net beklemtoon dat animus iniuriandi as vereiste vir iniuria in ons reg in beginsel sowel wilsgerigtheid as onregmatigheidsbewussyn as komponente verg. Daar kan egter weens beleidsoorwegings van onregmatigheidsbewussyn afgesien word. Dit het reeds gebeur met betrekking tot onregmatige vryheidsontneming, onregmatige beslaglegging op goed, die onregmatige inwerking op die persoonlikheidsgoedere van gevangenes en aanspreeklikheid van die media weens laster. Harms AP se teenoorgestelde obiter-siening dat animus iniuriandi in die algemeen nie onregmatigheidsbewussyn verg nie, word nie deur die oorwig van gesag gesteun nie. Al wat die hof in Le Roux $v$ Dey dienooreenkomstig te doen gestaan het, was om te bepaal of daar beleidsoorwegings bestaan het wat 'n afwyking van die vereiste "coloured intent" by laster buite om die media regverdig; en hier kom dit voor of die feit dat die vereiste tot onbillike resultate kan lei, en boonop die ontwikkeling van hierdie deel van ons reg onder die Grondwet aan bande lê, wel sodanige regverdiging bied. Dit is net jammer dat die hof nie, soos in Marais $v$ Groenewald supra, nalatigheidsaanspreeklikheid oorweeg het nie aangesien sodanige aanspreeklikheid die beskerming van die reg op die goeie naam as fundamentele reg veel meer as die (kleurlose) "intention to injure" wat die hof vereis het, sou bevorder het. 